\title{
Geleneksel Türk Seramiğinin Seramik Eğitimindeki Yeri
}

\author{
Vedat KACAR*
}

Özet

'Geleneksel Türk seramiği’ adlandırması günümüzde güzel sanatlar eğitiminde yaygın olarak kullanılmayan ancak 'çini’ olarak literatürde yer almış geleneksel üretim biçiminin bir karşılı̆ıdır. 'Geleneksel Türk seramiği’ yerine 'çini' teriminin kullanılıyor olmasının sektör ve eğitim alanlarında kavram kargaşasına neden olduğu konusunda görüşler bulunmaktadır. üretim yöntemleri ve kullanılan malzemelerin benzer olması öğrencilerin algısında bir yanılgı oluşturmaktadır. Bu yanılgı seramik ve çini üretimlerinin farklı uygulama ve tasarım alanları olarak algılanmasıdır. Çamur, sır, boya çeşitleri ve pişme dereceleri farklılık gösterse de ortaya çıkarılan ürünler/eserler aynı aileye aittir. Çini ürünlerin 'geleneksel seramik' olarak tanımlanması, bu kavramın daha doğru anlaşıımasını sağlar. Üretim serüveni ve şekillendirme aşamaları birbirinden farklı olmayan seramik ve çini eğitiminde her iki alanın birbirinden nasıl faydalanabileceği üzerine öneriler getirmek bu çalışmanın amacını oluşturmaktadır. Araştırmada, genel olarak 'çini' sanatı olarak kabul gören geleneksel Türk seramik üretim biçiminin ve bu üretim kapsamında kullanılan geleneksel form ve malzemelerin Seramik Bölümlerinde ne şekilde yer alması gerektiği üzerinde durulmuş, çağdaş Türk seramiği ile geleneksel Türk seramiğinin kimlik sorunu tartışılmıştır. Bu yolla günümüz seramik eğitiminde çağdaş ve geleneksel Türk seramiğinin hangi noktalarda birleşebileceği hakkında önerilerde bulunulmuştur.

Anahtar Sözcükler: Seramik Eğitimi, Çini, Geleneksel Türk Seramiği.

\section{The Situation of Traditional Turkish Ceramic in Ceramic Education}

\section{Abstract}

The term 'traditional Turkish ceramic', which is rarely used in fine arts education, includes the meaning of 'çini' referring to a traditional production style. There are debates about using the term 'çini' instead of the term 'traditional Turkish ceramic' causes conflict in the ceramic sector and education. Because the production methods and materials are similar, this creates a misimpression in students' understanding, which is presuming the ceramic and 'çini' education have different modes of application and design. Even the types of clay, glaze, painting and firing degrees show differences, the products/artworks that are formed are a part of the same family. Defining 'çini' artworks as 'traditional ceramic' will provide a better understanding of the term. The aim of this paper is to present suggestions about how both fields of study and application may benefit mutually, which have similar producing and forming styles. In this paper, it is intended to discuss in which ways the style of traditional Turkish ceramic production, which is generally known as art of 'çini', and the traditional forms and materials used in scope of this production can take place in Ceramic departments; in addition, the identity problem of contemporary and traditional Turkish ceramic is discussed. Thus, suggestions are made in terms of identifying points that can combine contemporary and traditional Turkish ceramic in today's ceramic education.

Keywords: Ceramic Education, Çini, Traditional Turkish Ceramic. 


\section{Giriş}

Seramik ilk ortaya çıkışından günümüze insanın yaşamını kolaylaştırmak, zenginleştirmek için kullandığı bilim, sanat, tasarım ve üretim sektörü içinde yer alan en temel malzemelerden birisidir. Özellikle son yıllarda bilim ve teknolojidekigelişmelerle geleneksel ya da yüksek teknoloji ürünü olarak günlük yaşamın içinde vazgeçilemeyecek disiplinler arası bir konumda yer almıştır. Seramik ve çini terimlerinin tanımlanmasına yönelik olarak ilgili alanlarda çeşitli araştırmalar yapılmıştır. Seramik bilim ve sanat alanlarında Türkçenin kullanım özelliklerinin terim ve kavram çerçevesinde incelendiği araştırmasında Hacızade (2014: 44), seramiğin çok zengin bir terim ve kavram varlığına sahip olduğunu, mühendislik, arkeoloji, fizik, kimya ve diğer tüm bilim dalları, sanat ve tasarım alanlarıla etkileşim halinde olduğu ve gelişiminin devam ettiğini belirtmektedir; bu konu hakkındaki kaynaklarda seramik, 'pişirilmiş kil mamulü', 'kil, killi toprak, çömlekçi toprağı ve topraktan yapılmış kap', 'kilden yapılmış ve pişirilmiş her tür eşyanın genel adı' şeklinde nitelendirilmektedir. Ateş Arcasoy’a göre (1983: 1) ise, seramik geleneksel bir anlatım dili ile "Organik olmayan malzemelerin oluşturduğu bileşimlerin, çeşitli yöntemler ile şekil verildikten sonra, sırlanarak veya sırlanmayarak sertleşip dayanıklılık kazanmasına varacak kadar pişirilmesi bilim ve teknolojisi” şeklinde tanımlanmaktadır.

Geleneksel Türk el sanatları ve seramik sanatı içinde önemli bir konuma sahip olan çini tanımı üzerine gerçekleştirilmiş araştırmalarda günümüze ulaşmış çini tanımı ile ilgili çelişkiler ve yanlış yönlendirmelerin tespit edildiği belirtilmektedir. Pala'nın (2014) Bazı Belge ve Tanımlarla 'Çini' Kelimesinin Değerlendirilmesi başlıklı araştırmasına göre çini 'çin' ile ilişkili bir kelimedir ve Çin'in ilişki kurduğu ülkelerde görülmektedir. 'Çin-i' kelimesinin sonundaki -i aitlik eki, Arapça 'Şini', Farsça ve Türkçe 'Çini', üretilen ürünün ya Çin'den geldiği ya da Çin'e atfedildiği anlamını taşımaktadır. Çin porselenlerinin kullanım eşyaları olmaları nedeni ile geçmişte 'çini' genellikle kullanım seramiklerini nitelemektedir. Mimari seramikler ise çoğunlukla sırça, kaşi gibi yöresel adlarla anılmaktadır. Geleneksel Türk Saray seramiği ile geleneksel çömlekçi ürünleri alanında araştırma yapılan Geleneksel Türk Sanatları Bölümü Çini Anasanat Dalı programlarında 'çini' kelimesi Geleneksel Türk seramiğini kapsamaktadır (Pala, 2014:12-14-19).

Öney’e göre (2000: 11), seramik ve çini temelde aynı olan ancak bilimsel ve akademik kaygılar nedeniyle farklı olarak değerlendirilen konulardır. Çağlar boyunca yaygın kullanımı seramik kapların adeta bir kültür tarihi gibi izlenmesi sonucunu doğurmuştur. Sırlı veya sırsız kullanım eşyası olarak üretilen kapların seramik, duvar kaplamasında aynı esaslarla üretilerek kullanılan levhaların çini olarak isimlendirilmesi tanımlamalarda kolaylık sağlanması amacıyladır. "Osmanlı da 'Çini' genel bir deyim-terim olarak yerleşmiş seramik ve çini ustaları 'duvar çinisi', 'çini tabak’ gibi terimleri Türkçeye kazandırıp yerleştirmişlerdir” (Öney, 2000: 11-14).

Geçmişten gelen çeşitli seramik gruplarının üretildikleri dönem içerisinde teknik ve görsel açıdan bir bütün oldukları ve birer maddi kültür varlığı olduklarından dolayı dönemleriyle beraber değerlendirilmiş oldukları ifade edilebilir. Çini ve seramik gibi kavramlar temelde aynı ailenin ürünleridir ve kavram kargaşası yaratmaması için 'çini'nin kelime olarak 'geleneksel seramik' adını alması çok daha yerinde olacaktır.

\section{Geleneksel Türk Seramiği ve Seramik Eğitimi}

Geleneksel Türk seramiği eğitimi ve seramik eğitiminin günümüzde program ve içerik açısından yeniden değerlendirmesi gereken iki bölüm olduğu düşünülmektedir. İki farklı bölüm olarak verilen eğitimin sonuçları incelendiğinde, seramik öğrencisinin geleneksel birikimlerden geleneksel seramik eğitimi alan öğrencinin de seramik programında yer alan çağdaş konulardan yararlandığı ya da yararlanmak istediği gözlenmektedir. Alan ile ilgili detaylı eğitim almadan üretilen form ve tasarımlarda arzu edilen görsel etkinin oluşmadığı görülmektedir. Bu sonuç çağdaş ve geleneksel Türk seramik sanatının geleceğini çok yakından ilgilendirmektedir.

Bu noktada iyi bir programla her iki bölüm öğrencilerinin doğru yönlendirilmesi ve daha uygun bir eğitim 
modelinin oluşturulması söz konusu olabilir mi, geçmiş birikimlerinin farkında ve bunları kullanma becerisi olan bir seramik bölümü öğrencisinin tasarımları daha nitelikli olabilir mi, geleneksel seramik bölümünde olan öğrencinin çağdaş seramik programlarından yararlanarak yapacağı çalışmalar çok daha nitelikli olabilir mi sorularının yanıtları önem kazanmaktadır. Türkiye'deki üniversitelerin program olarak geçtiği Bologna süreci ele alındığında kredi sistemleriyle bu iki disiplin birbirinden yararlanabilir mi sorusu bu çalışmanın temel amacını göstermektedir. Bu temel belki de Türk seramik sanatına önemli bir yapı taşı oluşturarak çağdaş seramik sanatı için önemli bir ivme kazanacaktır.

\section{Günümüzde Geleneksel Türk Seramiğinin Konumu}

Geleneksel Türk Seramik Sanatı, Türklerin Anadolu'ya girişleriyle başlayıp 800 yıl boyunca değişerek ve gelişerek kendi özgün tarzını oluşturmuş bir seramik kültürüdür. Cumhuriyet öncesi el sanatları içinde en belirgin olanlardan birisidir ve özgün tarzından dolayı dünyaca tanınmış bir sanat alanıdır. Geleneksel Seramik sanatını biçimlendiren irade dönemlerin sosyo-ekonomik koşullarında temelini İslam düşüncesinden almış ancak birbirinden farklı medeniyetlerin kaynaştığı bir yer olan Anadolu'da kendine has bir biçim, çizgi ve renk anlayışı geliştirmiştir. Türklerin gerek Orta Asya'da gerekse Anadolu'da yaşadıkları medeniyetler dolayısıyla büyük ve zengin bir kültür birikimine sahip olmaları ve bu birikimi gittikleri her yere taşımaları Anadolu'nun el sanatları hazineleri ile dolu olması, anayurdun el sanatları ve kültür merkezi olarak tanınmasında önemli bir etken olmuştur. Yine Anadolu'nun Asya'yı Avrupa'ya bağlayan bir köprü durumundaki stratejik coğrafi konumu ve buranın göç ve ticaret yolları üzerinde bulunması ayrıca bir önem kazanmasını sağlamıştır (Kahveci, 1998: 387).

Geleneksel sanatlar yüzyıllardır büyük bir çeşitlilik içinde toplumların duygularını ve sanatsal beğenilerini aktarma aracı olmuştur. Üretildikleri dönemin değer yargıları, toplumdaki politik eğilimler, ekonomik durum, din, kişilerarası örgütlenme ve ilişkiler, kişilerin davranış ve tutumları, teknik araç-gereç, beceri, estetik bakış açısı, dün- ya görüşü, ürünlere verilen biçim gibi etkenler geleneksel sanatlarının oluşumunu etkilemiştir.

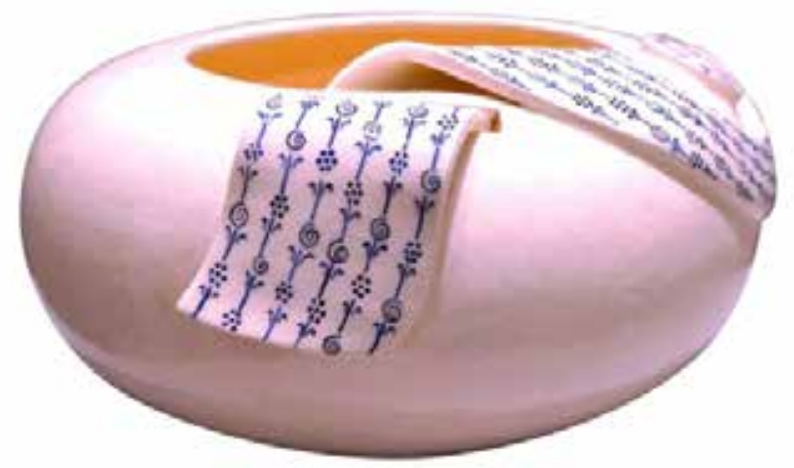

Fotoğraf 1. Banu Könteşlioğlu, Serbest Vazo Formu, Sıraltı Dekor, $30 \mathrm{~cm} \times 17 \mathrm{~cm}, 2011$ (Fotoğraf: Vedat Kacar).

Geleneksel Türk seramiği(diğer geleneksel sanatlar gibi) birincil özelliği işlevselliğidir. Çağımızdaki değişim geleneksel seramik ürünlerin işlevselliğinin büyük ölçüde kaybolmasına sebep olmuştur. Bu üretim amacının kayması olarak da ifade edilebilir. Çünkü geçmişte kullanım amaçlı gerçekleştirilen üretim bugün (mimaride kullanılanların dışında) süs eşyasına yönelmiştir (Fotoğraf 1-2-3). Süreç içinde Geleneksel Türk seramiği hızla değişen toplumsal beğenilerin ve isteklerin yanında buna paralel bir yenilenme gösteremediğinden yalnızca geçmişle bağlantı kuran eski-geleneksel bir sanat durumunda kalmıştır.

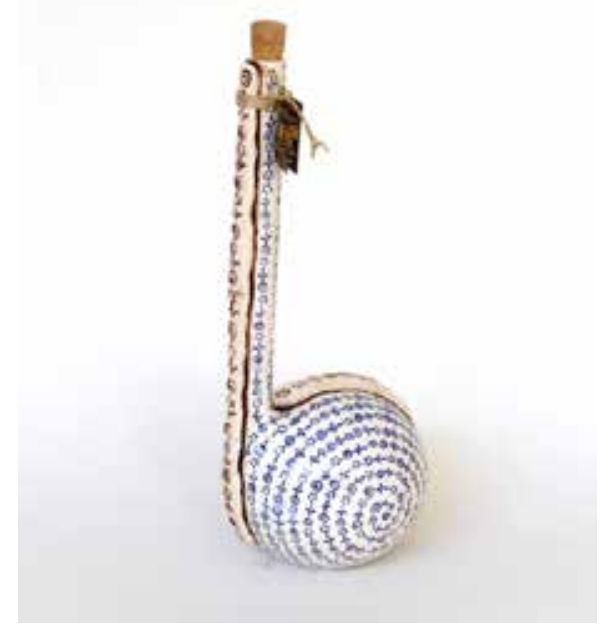

Fotoğraf 2. İmren Uludağ, Sıraltı Dekor, Zeytinyağı Şişesi, $13 \mathrm{~cm}$ x $30 \mathrm{~cm}, 2013$ (Fotoğraf: Vedat Kacar). 


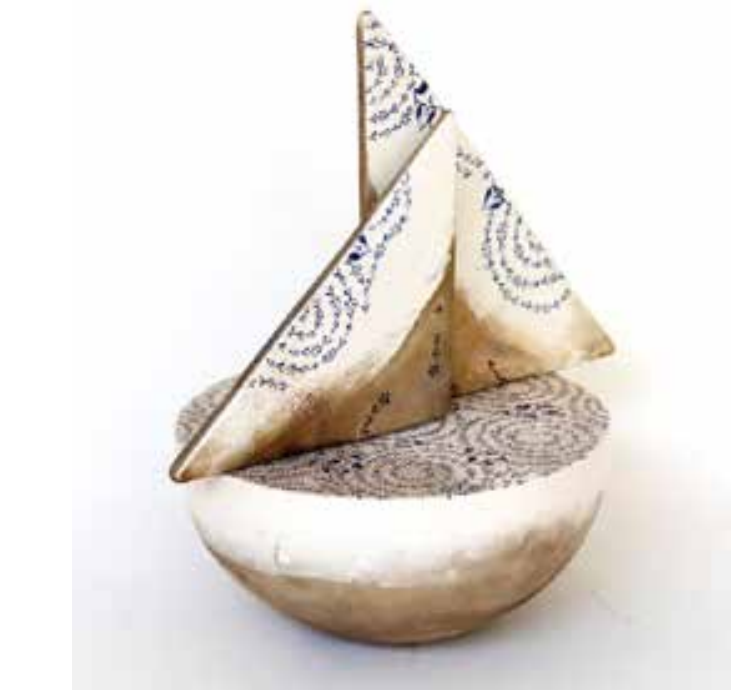

Fotoğraf 3. İmren Uludağ, Sıraltı Dekor, 20 cm x 30 cm, 2013 (Fotoğraf: Vedat Kacar).

Günümüzde geleneksel Türk seramiği koruma, yeniden üretme ve bunlara bağlı olarak yeni anlatım dilinin oluşturulmaması şeklinde tanımlanabilecek öncelikli sorunları vardır. Dolayısıyla önemli bir dönüm noktasından söz edilebilir. Bu durumda, geleneksel kalıplar içinde üretime devam edilecek ve geçmişe ait bir dönemin üretim tarzı olarak belki de bir süre sonra kaybolmaya yüz tutacaktır ya da bugünün sanat anlayışına da hitap edebilen yeni bir anlayış içinde olup aynı zamanda çağdaş Türk seramiğinin de bir parçası olma özelliği kazanacaktır. Bu gerçekleştiği takdirde son aşamada, tamamıla bugüne ait bir anlatım dilinin oluşmasını sağlayacaktır.
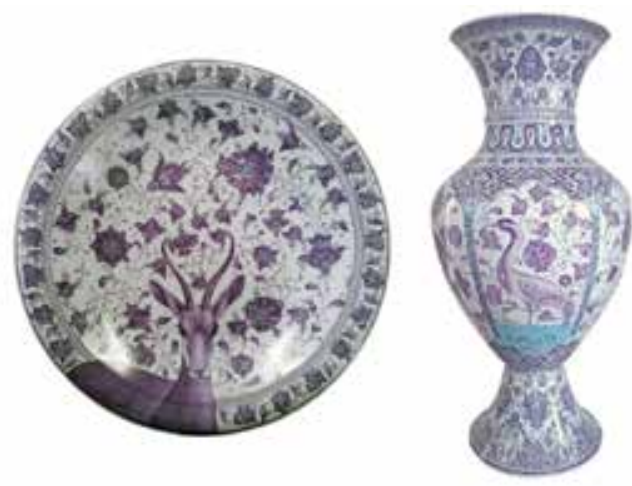

Fotoğraf 4. Mehmet Koçer, 2017, Sıraltı dekor, Tabak (solda) $50 \mathrm{~cm}$, Vazo (Sağda) Yükseklik: 1 metre (Fotoğraf: Vedat Kacar).

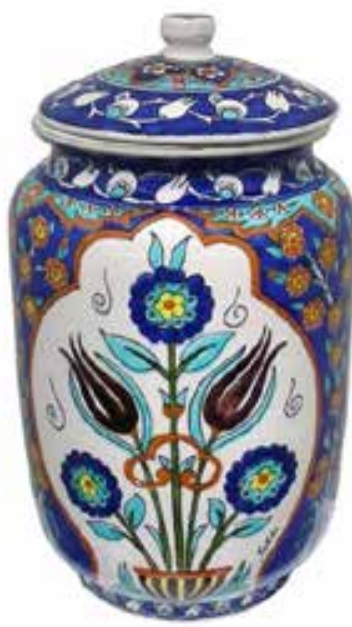

Fotoğraf 5. Sıtkı Olçar, Dekorlu Kapaklı Kavanoz, 2014 (Fotoğraf: Vedat Kacar).

Koruma kavramı, geleneksel üretimin iç dinamiği içinde geleneğine ve kurallarına uygun olarak sürdürülmesi, bir anlamda klasikleşmiş normların, anlayışların devam ettirilmesi olarak tanımlanabilir. Bugün geleneksel Türk seramiği üretilmesinde ticari kaygıların getirdiği problemler oldukça fazladır. Ancak bununla birlikte kalite açısından geleneksel üslup ve çizgileri koruyan oldukça başarılı atölyeler de mevcuttur. Hatta 16. yüzyılda üretilen geleneksel seramiklerden dekor anlamında çok daha kaliteli üretimler görülmektedir. Ancak bunun sınırlı sayıda olduğu söylenebilir (Fotoğraf 4-5). Bu bağlamda başarılı veya diğer (tamamen ticari kaygı taşıyı üretim yapan) atölyelerin önemli sorunlarından bir tanesi yeniden üretimdir.

Yeniden üretim, geleneksel üretimin iç dinamiğinin çağın koşullarında ve anlayışında yeniden ele alınmasıdır. Bugün üzerinde durulması gereken en önemli konu budur. Çünkü koruma konusu eğitim kurumlarında ve üretimin yapıldığı atölyelerde ele alınmaktadır. Ancak mevcut sınırların dışına çıkılmamaktadır. Bu yapılamadığı takdirde geleneksel Türk seramiği işlevselliğini yitireceği için yalnızca turistik eşya olarak varlığını sürdürebilecektir.

\section{Çağdaş Yeniden Üretim ve Eğitim Bağlantısı}

Çağdaş yeniden üretimde çıkış noktası geleneksel Türk seramiği olacaktır. Ancak çağdaş yeniden üretim sadece gelenekselin kendi sistematik değerleri içinde düzenlenmesi 
olarak anlaşılmamalıdır. Önemli olan gelenekseli ortaya çıkaran iç dinamiklerdir. Ortaya çıkan yeni tarz biçim, çizgi, renk veya kompozisyon anlayışı açısından geçmişle bağlantı kurabiliyorsa, aynı zamanda bugüne hitap edebiliyorsa değişimin halkası yakalanmış demektir (Fotoğraf 6-7-8). Bu durumda geleneksel Türk seramiği iç dinamiği, ruhu yaşatılabilir.

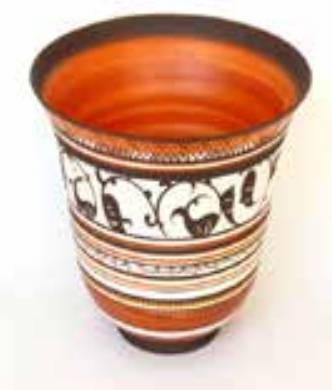

Fotoğraf 6. Sultan Çeşmeci, Dekorlu Kâse, 2015 (Fotoğraf: Vedat Kacar).

Geleneksel motiflerden esinlenerek analitik çözümlemelere gitmenin çağdaş sanat biçimlerini oluşturmada tek geçerli ve kesin bir yol olduğu iddiasında bulunmak yanlış olacaktır. Ancak sanatçı yaratıcılığının özgürlüğe bağlı olduğu ve bireysel atılımları yapıtın özgürlüğünü sağlamadaki gerekliliği göz önüne alındığında, geleneksel formun morfolojisi üzerinde incelemeler yapmak ve elde edilen bulguları değerlendirerek çağdaş yorumlara ulaşmak biçimselliğe yönelik bir yöntem olarak görünmektedir (Genç, 2013: 196).

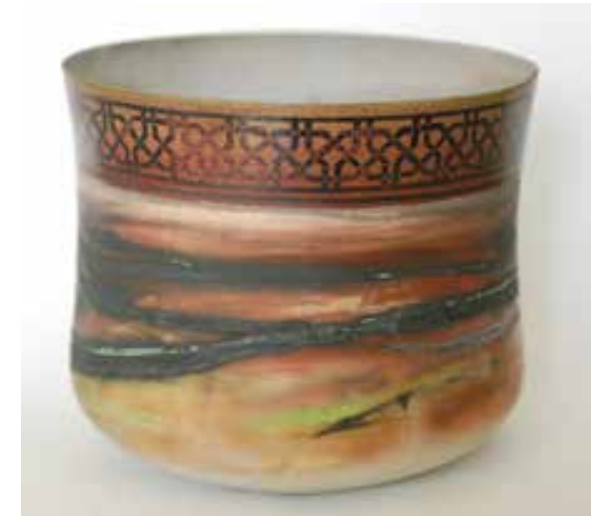

Fotoğraf 7. Kerem İldeş, Sagar Tekniğinde Çanak, Ağızda Sıraltı Dekor, 2012 (Fotoğraf: Vedat Kacar).
Geleneksel bir motifin içeriğini kavramadan onu olduğu gibi alıp kullanmak, geçmişteki bir sözcüğün bugünün cümlesinde yer almasına benzemektedir. 0 sözcük, içerdiği anlamı ile geçmişin bütününde değer taşımaktadır. Geleneksel değerlerin geçmişteki anlamlarını kavrayarak ona bugünün zamanından bakabilmeli ve onu geçmiş ile bugünün eş zamanlı bütünü içerisinde uyumlayabilmelidir. Sanatçının dili kendi zamanının dilidir. Kendi çağının bilincini taşıyabiliyorsa, geleneğini de niçin ve nasıl sorularına yanıt bularak geleceğe taşıyacaktır. Geleneksel Türk seramiği süslemeciliği öne çıkaran, yüzey etkisi güçlü olan bir sanattır. Dolayısıyla yeni bir anlatım dilinin oluşumunu belirleyecek olan bu çizginin gelişimidir.

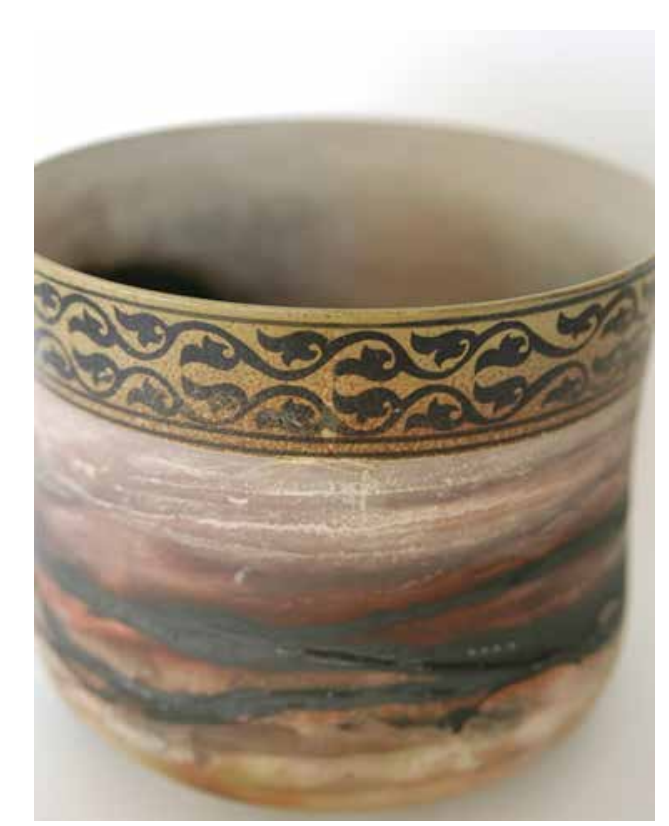

Fotoğraf 8. Kerem İldeş, Sagar Tekniğinde Çanak, Ağızda Sıraltı Dekor, 2012 (Fotoğraf: Vedat Kacar).

Yüzyıllar süren bir üretim sonunda zengin bir motif dili ortaya çıkmıştır. Bu motif dili kendine özgü bir biçim iradesine sahiptir. Çizgide başlayan farklıık, geleneksel Türk seramiği gelenekselliğini kaldıracak, sonuçta bugüne ait, bugünü anlatan bir anlatımı bulacaktır. Ancak daha önce de belirtildiği gibi bu en son aşamadır. Yeniden üretim olayı ilk basamaktır. Dün ile bugün arasında bir köprü bir ara sentez durumundadır. Geleneksel sanata bakışı yeni bir çerçeveye oturtmanın eğitimde değişime yönelik tavırların belirlenmesinde faydası olacaktır. Geleneksel seramik sa- 
natımızın eğitimdeki yeri ve ülkenin geleceği bakımından önemi üzerinde durulması tartışılması gereken önemli bir konu olduğunu düşünülmektedir.

Çağdaş yeniden üretimde ağırlıklı rol eğitim kurumlarına özellikle üniversitelere düşmektedir. Çünkü bu değişimi sağlayabilecek potansiyel ve birikim üniversitelerde mevcuttur. Yeninin yaratılması geleneksel tarz ile çağdaş seramik anlayışının birlikteliği ile mümkün olabilir. Anadolu yıllarca iki farklı kültürün, Doğu ve Batı kültürünün bir arada olduğu, çatıştı̆̆ı, yeni tarzlara vardığı kültürel mozaiğin merkezi olmuştur. Geleneksel Türk seramiği de o dönem koşullarında bu kaynaşmanın ürünüdür. Çağımız koşullarında bu kaynaşmaya, kendine özgü bir oluşuma yeniden varabilmek iki farklı anlayışın birbirini yok etmeden bir arada olabilmesiyle başarılabilir (Fotoğraf 9-10).

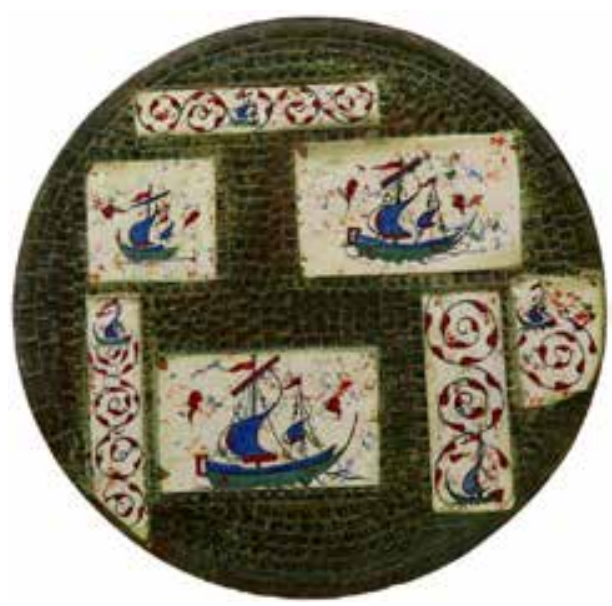

Fotoğraf 9. Vedat Kacar, Baskı Rölyef, Sıraltı Dekor, 60 cm Çap, 2016 (Fotoğraf: Vedat Kacar).

Türkiye'de geleneksel sanatlarla ilgili son dönemlerde ivme kazanmış olan akademik araştırmalar ve tartışmalar varılacak doğru sonuçlar bağlamında geçmiş ve gelecek arasında köprü kuracak ve var oluşun devamlılığını sağlayacaktır. Dolayısıyla konuyla ilgili tüm çalışmaların hedefi geleneksel ve klasik sanatları layık olduğu yere koymanın yolunu bulduracak nitelikte olmalıdır. Bunun için de ulusal kültürümüzün vazgeçilmez parçası bu sanatları objektif ve bilimsel metotlarla incelemek, geçmişteki en mükemmel şekli ile günümüze taşımak, severek ve sevdirerek bugünün yeni yorumları ile geliştirmek ve hayatın içinde yaşanır hale getirmek gerekir. Önyargılardan bağımsız olarak yapılacak bu arayışların kültürümüzün gelişmesinde mutlaka faydalı olacağına, yaşanılan dönem içinde daha itibarlı bir konuma getireceğine bir inanç oluşturmalıdır. Çağın koşullarında kendine özgü bir oluşuma yeniden varabilmek iki farklı anlayışın birbirini yok etmeden bir arada olabilmesi ile mümkündür. Günümüzde üniversitelerde geleneksel seramik eğitimi Geleneksel El Sanatları Bölümleri bünyesinde sürdürülmektedir. Bu bölümlerin eğitimlerini sürdürmeleri her ne kadar uzmanlaşma açısından yararlı olsa da asıl olan geleneksel seramik öğretiminin seramik bölümlerinde gereken ağırlığı kazanmasıdır. Bugün bazı üniversitelerde seramik bölümlerinde 'Türk Çiniciliği' veya 'Çinicilik Tarihi' adı altında verilen geleneksel seramik eğitimi ders saati ve kapsam itibariyle yeterli görünmemektedir.

Üniversite eğitim sistemi içinde öğrencilerin bu iki bölümden de belirlenecek olan dersleri almaları sağlanabilir ve ortak bir program hazırlanarak yönlendirmelerle verimli hale getirilebilir. Geleneksel seramik eğitiminde iç dinamiklerin kavratılması önemlidir. Bu çağdaş seramik ile geleneksel seramik arasındaki bağlantıyı sağlayacak ve öğrenci her iki anlayışı da iyi özümseyebildiği oranda kendi özgün yaratımlarını ortaya koyabilecektir.

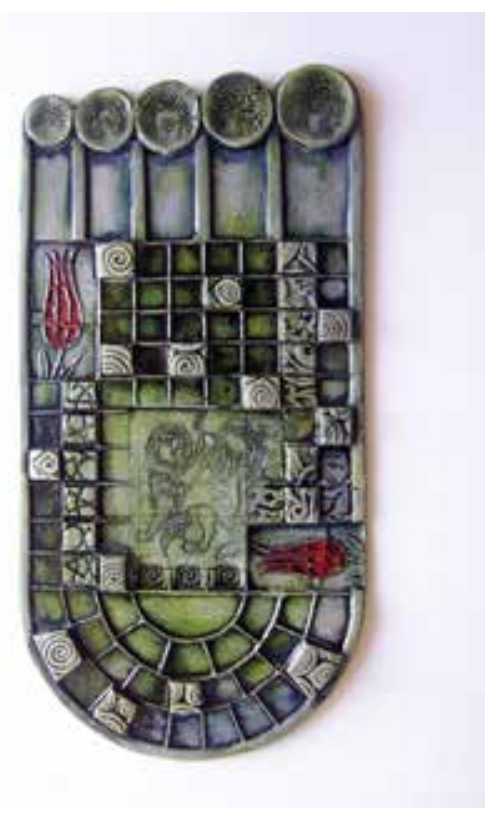

Fotoğraf 10. Vedat Kacar, Baskı Rölyef, Sıraltı Dekor, 35 cm x 50 cm, 2016 (Fotoğraf: Vedat Kacar). 


\section{Sonuç}

Geleneksel Türk seramiği eğitimi ve seramik eğitiminin günümüzde program ve içerik açısından yeniden değerlendirilmesi önem arz etmektedir. Bilim ve teknoloji alanlarındaki gelişmelerin insan yaşamını etkilediği ve buna bağlı olarak beğeni kavramları, estetik değerler ve öğrenci profillerinde değişime neden olduğu görülmektedir. Dolayısıyla, eğitim sistemindeki programların yenilenmesi uygun olacaktır. Bu bağlamda seramik bölümlerinde verilen dersler ile bugünkü adıyla Çini Ana Sanat Dalı'ndaki dersler karşılaştırılarak karşılıklı olarak birbirlerinden alabilecekleri derslerin belirlenip yeni program önerileri sunulmalıdır. Bu öneriler konu ile ilgili bir eğitim çalıştayı düzenlenerek çok daha doğru bir zemine oturtulabilir. Geleneksel seramik sanatının eğitimdeki yeri ve ülkenin geleceği bakımından önemi üzerinde durulması gereken önemli bir konu olduğu düşünülmektedir.

Çağdaş yeniden üretimde eğitim kurumlarına özellikle Güzel Sanatlar Fakültelerine önemli rol düşmektedir. Konu ile ilgili araştırmacıların gerçekleştireceği bilimsel, sanatsal ve tasarıma yönelik çalışmalar, araştırmalar ve ulaşılacak doğru sonuçlar önemli adımlar kazandıracaktır. Geleneksel seramik eğitiminin teorik ve pratik olarak temelden, iç dinamiklerinin dikkate alınarak verilmesi gerekmektedir. Ancak bu şekilde çağdaş seramik anlayışı ile geleneksel anlayışı birbirinden ayrı düşünmemek aralarında bir bağlantı kurmak mümkün olacak ve tasarımlardaki yaratıcılığın olumlu yönde gelişmesini sağlayacaktır. Çağdaş Türk seramiğinin anlatım dilinin oluşumunda geleneksele ait birikimlerin göz ardı edilmemesi gerekmektedir çünkü yeniyi yaratmada gerekli ipuçları gelenekselde mevcuttur.

Seramik malzemelerinin ifade gücünden yararlanarak geleneksel seramik sanatının biçim dilini bugünün renk, malzeme ve teknolojik özellikleriyle birlikte düşünerek harmanlamak, bu konuda kendine özgü farklı çizgisi olan yeni eğilimlere kapı açacaktır. Mevcut eğitim sistemi ile düzenlenip temelleri atılacak olan bu programın önerisi, eğitim sürecini tamamlayan öğrencilerin ürettikleri sanat eserlerinde kendilerini gösterebilmeleri geleneksel ve çağdaş seramik sanatı açısından önemli bir adım olacaktır.

\section{KAYNAKÇA}

Ağatekin, M. (2012). Dünyada ve Türkiye'de Çağdaş Seramik Sanatının Oluşum Süreci, Eskişehir: Anadolu Üniversitesi Yayınları.

Arcasoy, A. (1983). Seramik Teknolojisi, İstanbul: Marmara Üniversitesi Yayın No:2, Güzel Sanatlar Fakültesi Yayın No: 2.

Arlı, M. (1994). “El Sanatlarında Yozlaşma Örnekleri”, Kamu ve Özel Kuruluşlarla Orta Öğretimde, Üniversitelerde El Sanatlarına Yaklaşım ve Sorunları Sempozyumu, Kültür Bakanlığı Yayınları: 201, Maddi Kültür Dizisi: 11, Türk Tarih Kurumu Basımevi. Ankara, 19-20.

Barışta, H. Ö. (1996). "Yaygın Eğitim Kurumları Programlarındaki Geleneksel Türk EI Sanatları Üzerine”, Türkiye’de El Sanatları Geleneği ve Çağdaş Sanatlar İçindeki Yeri Sempozyumu, Kültür Bakanlığı Yayınları: 18, 198-202.

Birol, İ. (1996). “Geleneksel Sanatların Eğitimdeki Yeri ve Önemi”, Türkiye'de El Sanatları Geleneği ve Çağdaş Sanatlar İçindeki Yeri Sempozyumu, Kültür Bakanlığı Yayınları, 195-197.

Çakı, M. \& Kacar, V. (1999). “Geleneksel Türk Çini Sanatı ve Tasarım Sorunları”,2000’li Yıllarda Türkiye’de Geleneksel Türk El Sanatlarının Sanatsal Tasarımsal ve Ekonomik Boyutu Sempozyumu Bildirileri, Kültür Bakanlığı Yayınları, Ankara, 96-98.

Çalışıcı Pala, İ. (2014). "Bazı Belge ve Tanımlarla 'Çini' Kelimesinin Değerlendirilmesi”, Yedi: Sanat Tasarım ve Bilim Dergisi (13), 11-24.

Genç, M. (2013). “Gelenek ve Modernite Arasında Geleneksel Türk Sanatları”, Sakarya Üniversitesi GSF 1. Uluslararası Sanat Sempozyumu, 21-23 Kasım 2013.

Hacızade, F. (2014). "Seramik Alanında Kullanılan Terim ve Kavramlarda Türkçenin Durumu”, Selçuk Üniversitesi Türkiyat Araştırmaları Dergisi (35), 39-54.

Kahveci, M. (1998). “21. Yüzyıla Girerken Geleneksel Türk Sanatları", Folkloristik Pars Yılı, Prof. Dr. Dursun Yıldırım Armağanı, Ankara, 389-392. 
Öney, G. (2000). “Çini-Seramik Öyküsü”, Osmanlı’da Çini ve Seramik Öyküsü, ed: A. Altun, Creative yayıncılık ve Tanıtım Ltd. Şti.

Sürür, A. (1994). “21. Yüzyılda Geleneksel Türk El Sanatları İçin Öneri ve Önlemler”, Kamu ve Özel Kuruluşlarla Orta Öğretimde, Üniversitelerde El Sanatlarına Yaklaşım ve Sorunları Sempozyumu, Kültür Bakanlığı Yayınları: 201, Maddi Kültür Dizisi: 11, Türk Tarih Kurumu Basımevi, Ankara, 431-434.

\section{Görsel Kaynakça}

Fotoğraf 1. Könteşlioğlu, B., Serbest Vazo Formu, Sıraltı Dekor, 2011, $30 \mathrm{~cm} \times 17 \mathrm{~cm}$, Fot: V. Kacar.

Fotoğraf 2. Uludağ, İ.. Sıraltı Dekor, Zeytinyağı Şişesi, 2013, $13 \mathrm{~cm}$ x $30 \mathrm{~cm}$, Fot: V. Kacar.

Fotoğraf 3. Uludağ, İ., Sıraltı Dekor, 2013, $20 \mathrm{~cm} \times 30 \mathrm{~cm}$, Fot: V. Kacar.

Fotoğraf 4. Koçer, M., Sıraltı dekor, 2017, Tabak (solda) $50 \mathrm{~cm}$, Vazo (Sağda) Yükseklik: 1 metre, Fot: V. Kacar.

Fotoğraf 5. Olçar, S., Dekorlu Kapaklı Kavanoz, 2014, Fot: V. Kacar.

Fotoğraf 6. Çeşmeci, S., Dekorlu Kâse, 2015, Fot: V. Kacar.

Fotoğraf 7. İldeş, K., Sagar Tekniğinde Çanak, Ağızda Sıraltı Dekor, 2012, Fot: V. Kacar.

Fotoğraf 8. İldeş, K., Sagar Tekniğinde Çanak, Ağızda Sıraltı Dekor, 2012, Fot: V. Kacar.

Fotoğraf 9. Kacar, V., Baskı Rölyef, Sıraltı Dekor, 2016, 60 cm Çap, Fotf: V. Kacar.

Fotoğraf 10. Kacar, V., Baskı Rölyef, Sıraltı Dekor, 2016, $35 \mathrm{~cm}$ x $50 \mathrm{~cm}$, Fot: V. Kacar. 